\title{
Arthroascus fermentans, a New Yeast Species Isolated from Soil in Taiwan
}

\author{
CHING-FU LEE, ${ }^{1} \dagger$ FWU-LING LEE, ${ }^{1 *}$ WEN-HAW HSU, ${ }^{1}$ AND HERMAN J. PHAFF ${ }^{2}$ \\ Food Industry Research and Development Institute, Hsinchu 300, Taiwan, Republic of China, ${ }^{\mathrm{I}}$ and \\ Department of Food Science and Technology, University of California,
} Davis, California $95616^{2}$

\begin{abstract}
Arthroascus fermentans, a new arthrosporous, fermenting, ascogenous yeast species, is described. The three strains of the species included in this study were isolated from soil samples obtained from different orchards in Taiwan. The species is homothallic, and the major ubiquinone isoprenolog is Q-8. DNA hybridization and DNA base composition data indicate that $A$. fermentans is a species that is distinct from previously described Arthroascus species. The type strain of $A$. fermentans is strain 80D2303, which has been deposited in the Culture Collection and Research Center, Food Industry Research and Development Institute, Hsinchu, Taiwan, as strain CCRC 22530.
\end{abstract}

The first species in the genus Arthroascus von Arx was originally described as Endomyces javanensis (5) in 1909. In 1931, this organism was placed in a new genus, Endomycopsis (9), and finally in 1972 it was assigned to another new genus, Arthroascus (12). In 1985, some strains of Arthroascus javanensis isolated from oak exudate in Russia were reclassified in a new species, Arthroascus schoenii, on the basis of differences in the nature of sporulation and in genetic characteristics from the type strain of $A$. javanensis (1).

During the isolation of yeasts from carambola and papaya orchard soils in Taiwan, we identified three strains of a previously undescribed yeast species belonging to the genus Arthroascus. These strains were characterized by the formation of budding cells, arthrospores, and spindle-shaped asci containing two to four flattened, spherical spores with thin ledges. The major ubiquinone was Q-8. Our isolates exhibited low levels of DNA relatedness to the previously described $A r$ throascus species. A new species, Arthroascus fermentans, is proposed for these yeasts.

\section{MATERIALS AND METHODS}

Yeast strains. The three strains which we studied, strains $80 \mathrm{D} 2303^{\mathrm{T}}$ ( $\mathrm{T}=$ type strain), 80D2406, and 80D2412, were isolated in December 1991 from soil samples collected in a papaya orchard in I'lan, Taiwan, and in carambola orchards in Hualein, Taiwan. A. schoenii CCRC 21401 (= CBS 6423), CCRC $22503^{\mathrm{T}}\left(=\mathrm{CBS} 7223^{\mathrm{T}}\right)$, and CCRC 22504 (= CBS 7425 ) and $A$. javanensis $\mathrm{CCRC} 21392^{\mathrm{T}}\left(=\mathrm{CBS} 2555^{\mathrm{T}}\right)$ were used for taxonomic comparisons.

Examination of morphological, physiological, and biochemical characteristics. Morphological, physiological, and biochemical characteristics were determined by the methods described by van der Walt and Yarrow (11).

Morphological examination by scanning electron microscopy. Organisms were examined by scanning electron micros-

\footnotetext{
* Corresponding author. Mailing address: Food Industry Research and Development Institute, P.O. Box 246, Hsinchu 300, Taiwan, Republic of China. Phone: 886-35-223191. Fax: 886-35-214016.

$\dagger$ Present address: Yuan Pei Junior College of Medical Technology, Hsinchu 300, Taiwan, Republic of China.
}

copy by using a minor modification of the method described by Nakase et al. (7).

Cells grown in YPD broth (2\% glucose, $2 \%$ peptone, $1 \%$ yeast extract) or agar blocks containing mycelia, liberated ascospores, and vegetative cells were prefixed in $2 \%$ glutaraldehyde and then fixed in a vapor consisting of $1 \%$ osmic acid in $0.1 \mathrm{M}$ phosphate buffer $(\mathrm{pH}$ 7.2). The fixed specimens were gradually dehydrated by passing them at 15 -min intervals through a graded series of acetone concentrations ranging from 30 to $100 \%$ and then were transferred to isoamyl acetate for more than $1 \mathrm{~h}$. Finally, the samples were put in a model HCP-2 critical point drying apparatus (Hitachi) and dried.

The dried specimens were coated with gold at $1.2 \mathrm{kV}$ and $5 \mathrm{~mA}$ in vacuo and were examined with a model 450 scanning electron microscope (Hitachi) operated at 15 or 20 $\mathrm{kV}$.

Ubiquinone system. Cells were grown at $25^{\circ} \mathrm{C}$ in $100 \mathrm{ml}$ of YPD liquid medium containing $1 \mathrm{~g}$ of yeast extract, $2 \mathrm{~g}$ of Bacto Peptone (Difco), and $2 \mathrm{~g}$ of glucose and were collected in the early stationary phase of growth. The cells were washed with distilled water, and ubiquinones were extracted and purified by the method of Collins et al. (3). Ubiquinone isoprenologs were identified by high-performance liquid chromatography (HPLC) by comparing the retention times of the compounds with the retention times of standard ubiquinones purchased from Sigma Chemical Co. HPLC was performed with a model 740 liquid chromatography apparatus (Waters) fitted with a Zorbas octyldecyl silane column ( $4.6 \mathrm{~mm}$ by 25 $\mathrm{cm})$. The ubiquinones were eluted with a methanol-isopropanol $(2: 1, \mathrm{vol} / \mathrm{vol})$ mobile phase at a flow rate of $1.0 \mathrm{ml} / \mathrm{min}$ and were detected at $275 \mathrm{~nm}(7)$.

DNA base composition. Cells were grown in YPD broth at $25^{\circ} \mathrm{C}$ and collected in the late logarithmic phase of growth. DNA was isolated and purified by the method of Kaneko and Banno (4). The purified DNA was hydrolyzed with nuclease P1 (Boehringer Mannheim Co.), and the resulting deoxyribonucleosides were digested with alkaline phosphatase (Sigma). The molar ratio of deoxyribonucleosides in the reaction mixture was determined by HPLC performed with a model 740 liquid chromatography apparatus (Waters) fitted with a Cosmosil C18 column (Nacalai Chemicals Co.). The deoxyribonucleosides were eluted with a mobile phase consisting of a 0.2 

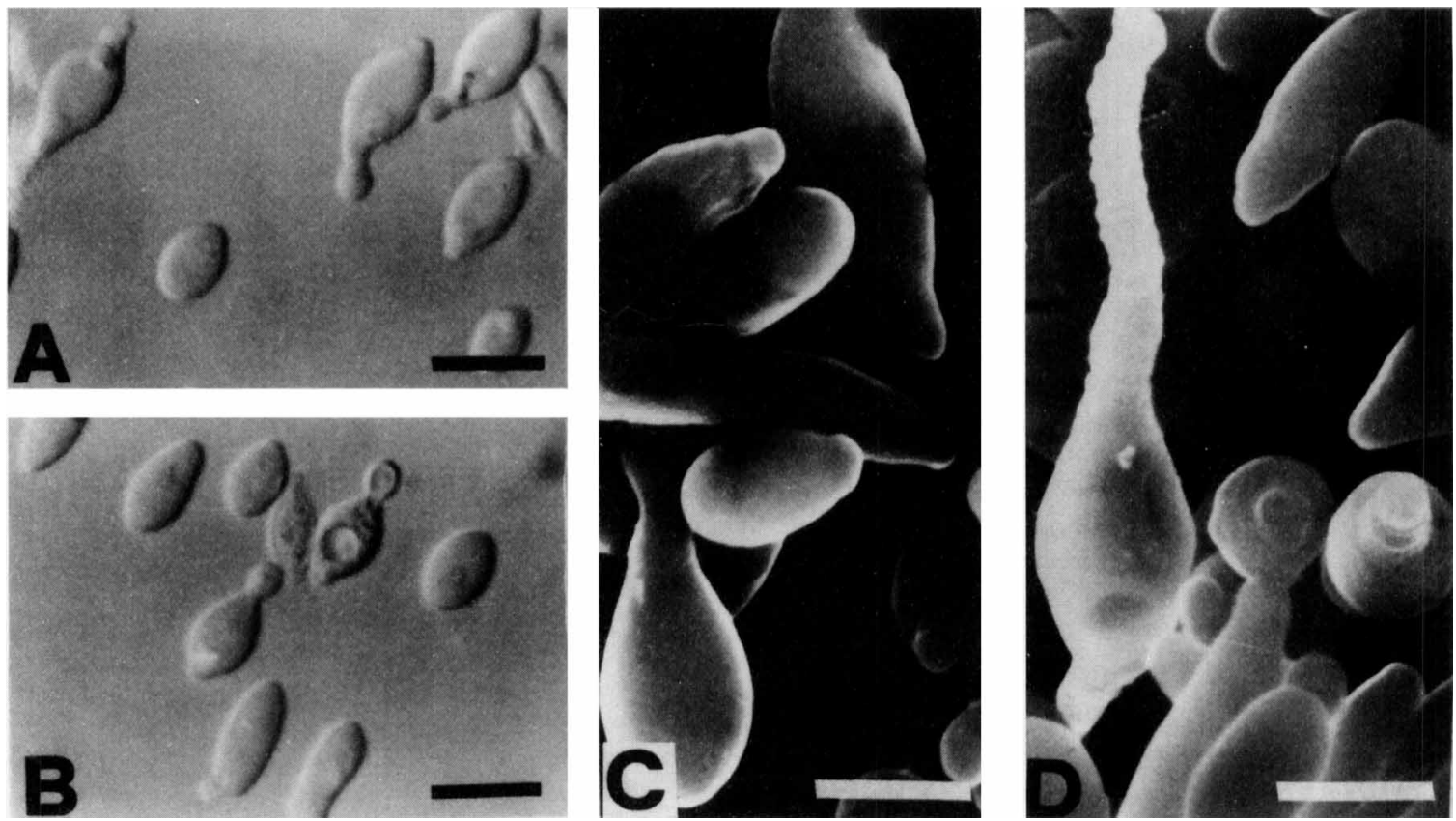

FIG. 1. Morphology of $A$. fermentans $80 \mathrm{D} 2303^{\mathrm{T}}$ as determined by light microscopy (A and B) and scanning electron microscopy (C and D). The yeast strain was cultivated in $0.5 \%$ yeast extract- $2 \%$ glucose broth for 3 days at $25^{\circ} \mathrm{C}$. (A and B) Bars $=10 \mu \mathrm{m}$. $(\mathrm{C}$ and $\mathrm{D}) \mathrm{Bars}=5 \mu \mathrm{m}$.
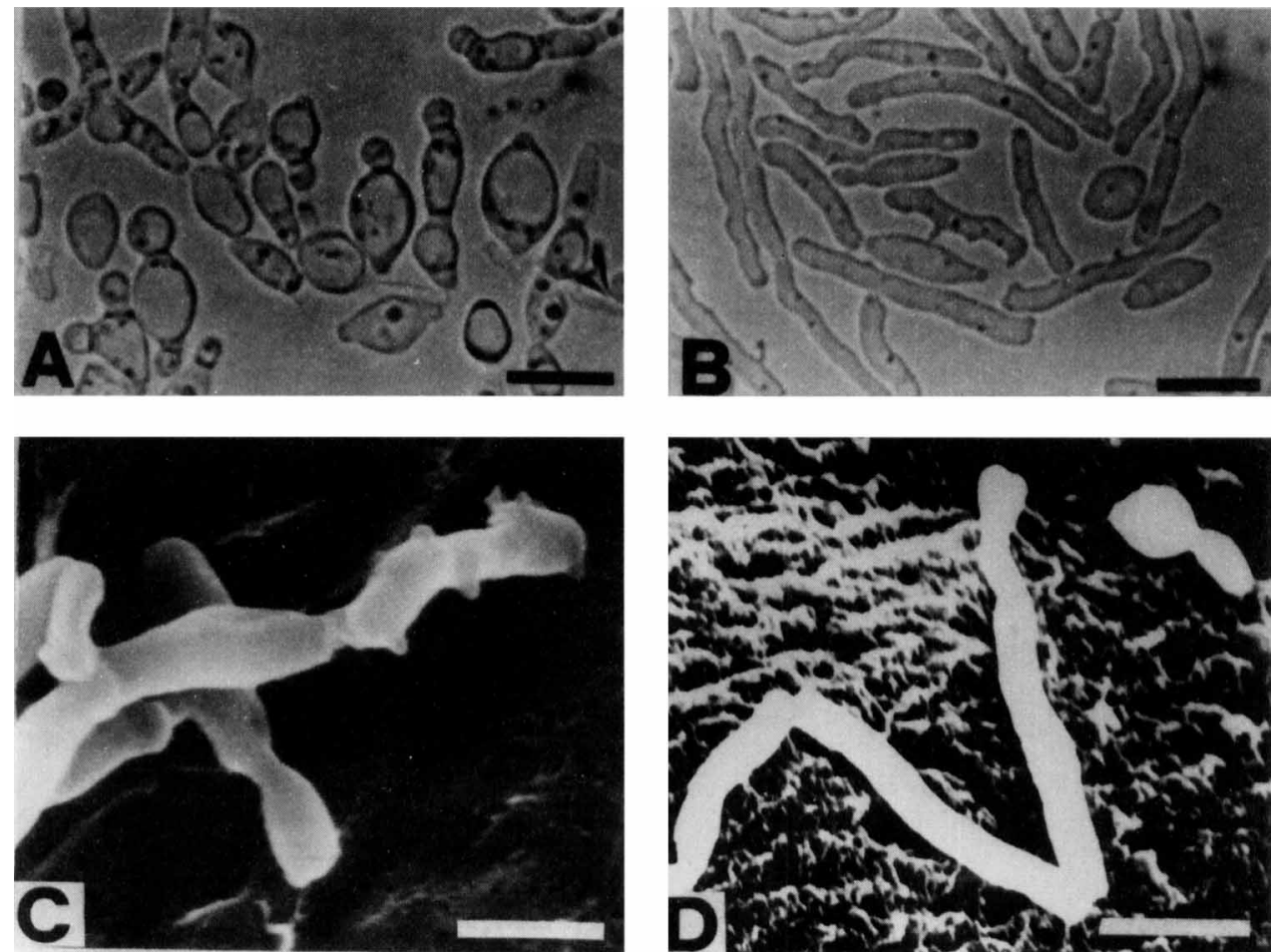

FIG. 2. Morphology of $A$. fermentans $80 \mathrm{D} 2303^{\mathrm{T}}$ as determined by light microscopy (A and $\mathrm{B}$ ) and scanning electron microscopy (C and D). The yeast strain was cultivated on $\mathrm{YM}$ agar at $25^{\circ} \mathrm{C}$ for 3 days. (A) Septa between cells and buds. (B) Elongate cells. (C) Tooth-like appendages around the mycelium. (D) Formation of arthrospores. (A, B, and D) Bars $=10 \mu \mathrm{m}$. (C) Bar $=5 \mu \mathrm{m}$. 

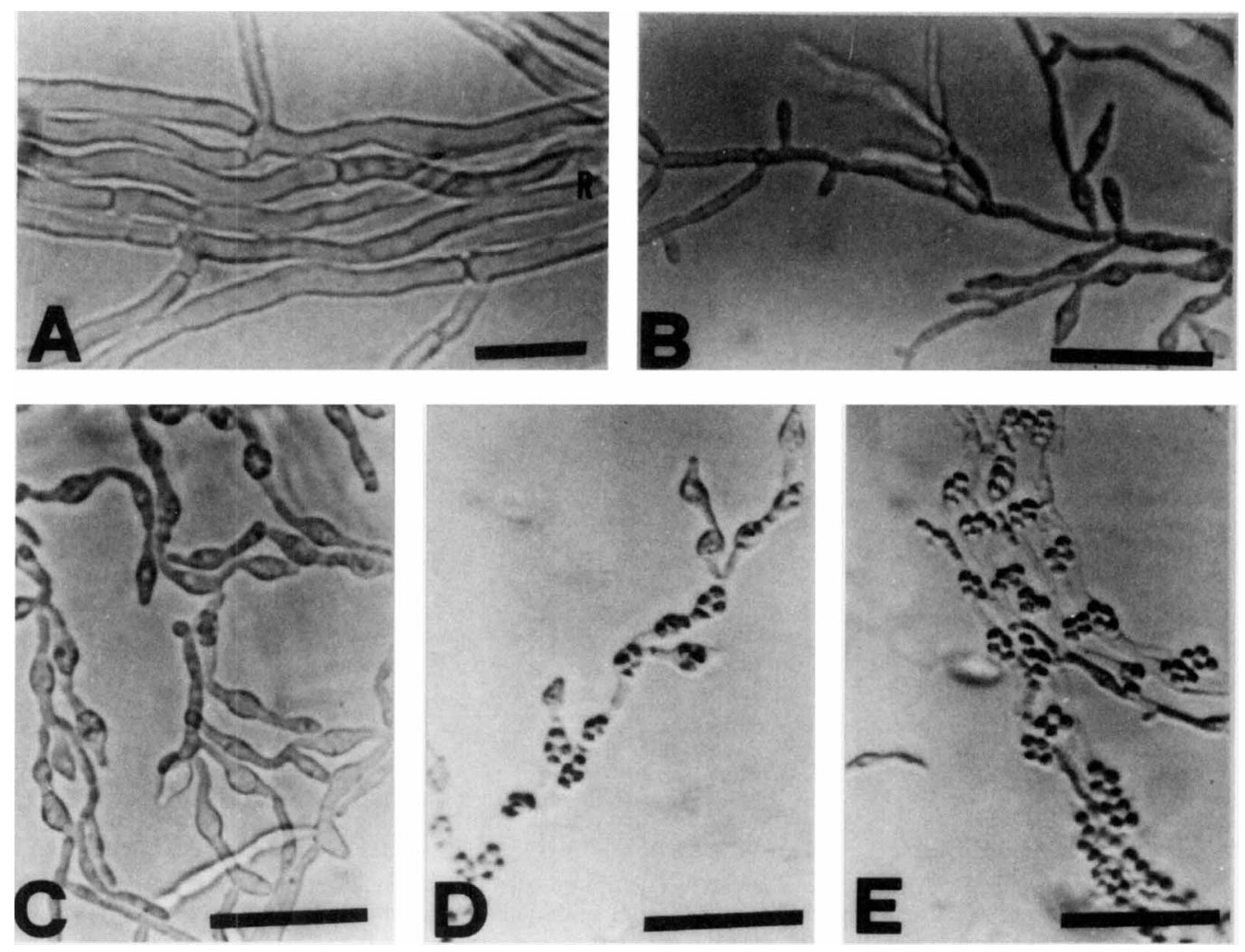

FIG. 3. Dalmau plate culture of $A$. fermentans $80 \mathrm{D} 2303^{\mathrm{T}}$ grown on corn meal agar for 7 days at $25^{\circ} \mathrm{C}$. (A) True mycelium. (B) Pseudomycelium. (C) Spindle-shaped asci. (D and E) Pseudomycelium containing spores. (A) Bar $=10 \mu \mathrm{m}$. (B through E) Bars $=40 \mu \mathrm{m}$.

M ammonium dihydrogen phosphate solution supplemented with 0.05 volume of acetonitrile. A standard deoxyribonucleoside mixture was prepared by digesting a standard deoxyribonucleotide DNA-GC kit (Yamasa Shoyu Co.) mixture with alkaline phosphatase (10).

DNA relatedness. DNA relatedness values were determined by the photobiotin-labeling microplate method described by Kaneko and Banno (4).

\section{RESULTS}

Latin diagnosis of Arthroascus fermentans sp. nov. In medio liquido post dies 3 cellulae singulae vel binae, cellulae ovoidae vel apiculatae $(3.2-7.2$ by $4.8-14.4 \mu \mathrm{m})$. Post 1 mensem sedimentum formatur.

Cultura in agaro malti post 1 mensem $\left(25^{\circ} \mathrm{C}\right)$, cremea vel brunneola, butyrosa, nitida, plana, nugosa, margine pilosa.

In agaro farinae Zea mays post dies 10 mycelium et pseudomycelium formantur.

Species homothallica. Asci conjugati vel inconjugati, habentes 2-4 sporae oblato-ellipsoidales aut lentiformis habens anulum tenuis in medio.

Asci deliquescens.

Fermentatio glucosi.

Glucosum, trehalosum (lente), glycerolum (lente), ethanolum assimilantur, at non galactosum, L-sorbosum, D-xylosum, L-arabinosum, D-arabinosum, L-rhamnosum, saccharosum, maltosum, $\alpha$-methyl-D-glucosidum, cellobiosum, salicinum, $\mathrm{N}$ acetyl-D-glucosaminum, arbutinum, melibiosum, lactosum, raffinosum, melezitosum, inulinum, amylum solubile, erythritolum, ribitolum, xylitolum, L-arabinitolum, D-glucitolum,
D-mannitolum, galactitolum, inositolum, glucono- $\delta$-lactonum, acidum 2-ketogluconicum, acidum 5-ketogluconicum, acidum D-gluconicum, acidum D-glucuronicum, acidum D-galacturonicum, acidum DL-lacticum, acidum succinicum, acidum citricum, methanolum, acetonum, 2-propanolum, hexadecanum, nec ethyl acetas.

Lysinum assimilatur at non ethylaminum, cadaverinum, natrium nitricum, nec natrium nitrosum.

Augmentum in $30^{\circ} \mathrm{C}$ at non in $37^{\circ} \mathrm{C}$.

Ad crescentiam vitaminae externae necessariae sunt.

Materia amyloidea iodophila non formatur.

Ureum non hydrolysatur.

Diazonium caeruleum B: negativum.

Proportio guanini + cytosini in acido deoxyribonucleati: 36.5-37.5 mol\% (per HPLC).

Ubiquinonum primus: Q-8.

Typus ex terra in I'Lan, Taiwan, isolata est. In Culture Collection and Research Center (CCRC), Food Industry Research and Development Institute, Hsinchu, Taiwan, sub no. 80D2303 ( = CCRC 22530) deposita est.

Description of Arthroascus fermentans sp. nov. Arthroascus fermentans (fer' men. tans. L. part. adj. fermentans, fermenting, referring to the ability of the organism to ferment glucose vigorously). After growth in $0.5 \%$ yeast extract-2\% glucose broth for 3 days at $25^{\circ} \mathrm{C}$ the cells are ellipsoidal, long ovoidal, and lemon shaped to elongate ( 3.2 to 7.2 by 4.8 to $14.4 \mu \mathrm{m}$ ) (Fig. 1A and B). Buds are formed on broad bases at the extremities of the cells (Fig. 1C and D). A sediment is formed after 1 month.

After growth on YM agar (Difco) at $25^{\circ} \mathrm{C}$ for 3 days septa develop between buds and parent cells (Fig. 2A); short true 

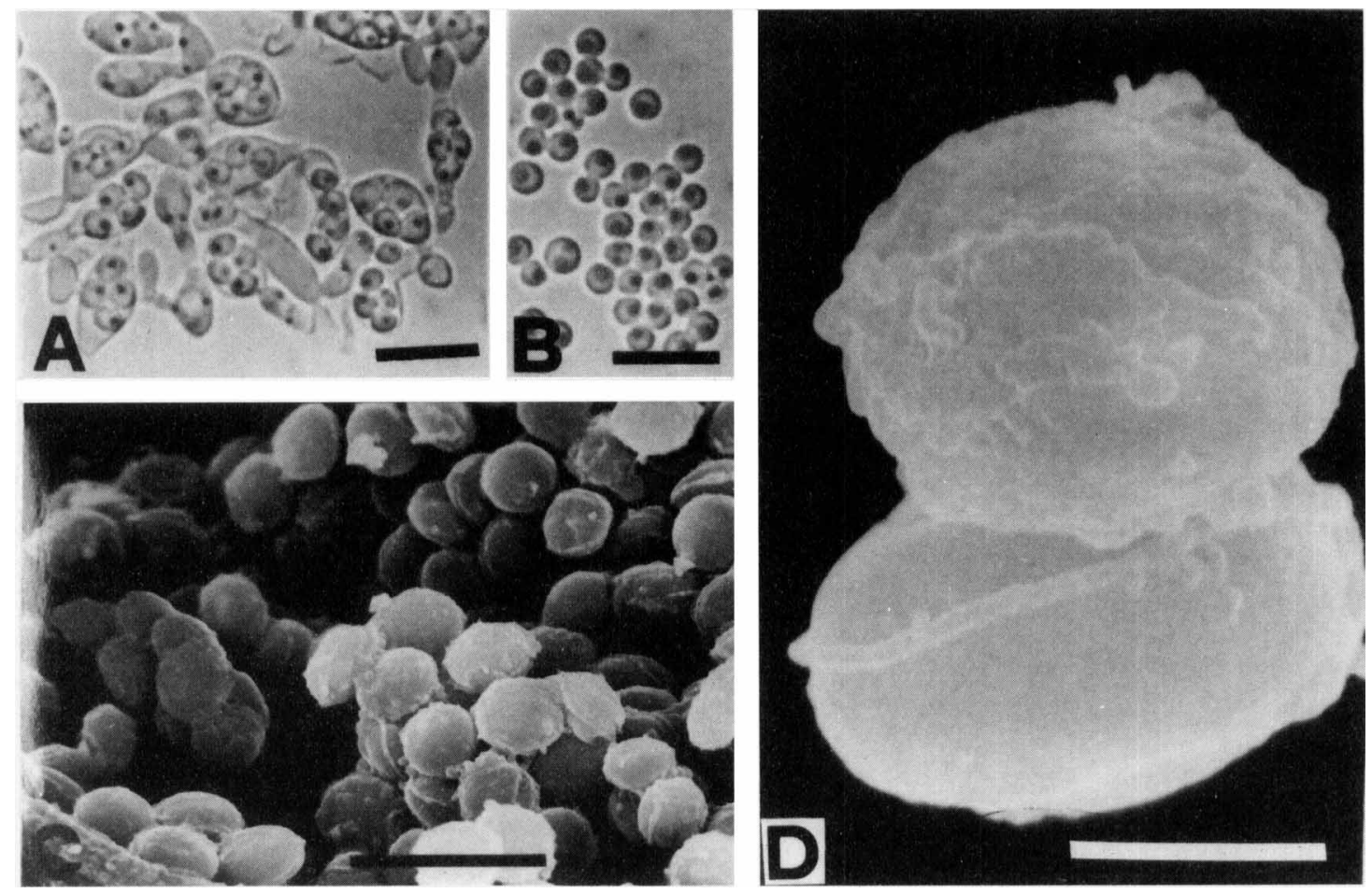

FIG. 4. Sporulation of $A$. fermentans $80 \mathrm{D} 2303^{\mathrm{T}}$ as determined by light microscopy (A and $\mathrm{B}$ ) and scanning electron microscopy (C and D). The yeast strain was cultivated on acetate agar for 3 days at $25^{\circ} \mathrm{C}$. (A) Conjugation and ascus formation. (B and C) Agglutinated spores. (D) Spore morphology. (A and B) Bars $=10 \mu \mathrm{m}$. (C) Bar $=5 \mu \mathrm{m}$. (D) Bar $=1 \mu \mathrm{m}$.

hyphae or pseudomycelia form (Fig. 2B), which break up into arthrospores (Fig. 2D). All strains produce short lateral denticles (Fig. 2C).

After growth on $5 \%$ malt extract agar for 1 month at $25^{\circ} \mathrm{C}$ streak cultures are creamy to brownish, butyrous, dull, flat, wrinkled, and fringed with pseudomycelia.

On Dalmau plate cultures on corn meal agar after 10 days at $25^{\circ} \mathrm{C}$ abundant pseudomycelia and true mycelia with phasedark septa develop (Fig. 3A and B). Some elongate cells are transformed into pouches, which usually contain four spores; the pouches (asci) become highly inflated in the middle (Fig. $3 \mathrm{C}$ through $\mathrm{E})$.

Sporulation (formation of ascospores) occurs on YM agar, potato-dextrose agar, acetate agar, and malt extract agar after incubation at $25^{\circ} \mathrm{C}$ for 3 days, as well as in Dalmau corn meal plate cultures after 7 days. Cells may be transformed directly into asci, or conjugation between two cells occurs and the zygote inflates in the middle and is then transformed into a spindle-shaped ascus (Fig. 3C through E and 4A). Usually each ascus contains four spores; less frequently an ascus contains two spores. Each spore is oblate ovoidal and has a narrow equatorial ledge and smooth surface (Fig. 4C and D). As soon as the asci mature, the spores are liberated and agglutinate (Fig. 4B and C). All strains are homothallic, as determined by the method of Wickerham and Burton (13).

Ferments D-glucose, but does not ferment $\alpha, \alpha$-trehalose, raffinose, $\mathrm{D}$-galactose, melibiose, inulin, maltose, lactose, starch, $\alpha$-methyl-D-glucoside, cellobiose, D-xylose, sucrose, and melezitose.

Assimilates the carbon in D-glucose and ethanol. Assimilation of the carbon in glycerol is positive or latent. Assimilation of the carbon in $\alpha, \alpha$-trehalose is latent. Does not assimilate the carbon in soluble starch, DL-lactate, galactose, D-xylose, eryth- ritol, succinate, L-sorbose, L-arabinose, ribitol, citrate, sucrose, $\mathrm{D}$-arabinose, galactitol, myo-inositol, maltose, D-ribose, L-arabinitol, hexadecane, cellobiose, L-rhamnose, xylitol, 2-ketogluconate, D-glucosamine, D-mannitol, 5-ketogluconate, lactose, $\mathrm{N}$-acetylglucosamine, D-glucitol, D-galacturonate, melibiose, D-glucono-1,5-lactone, $\alpha$-methyl-D-glucoside, acetone, raffinose, arbutin, salicin, 2-propanol, melezitose, methanol, Dgluconate, ethylacetate, inulin, and D-glucuronate.

Does not assimilate the following nitrogen sources: nitrate, nitrite, ethylamine, and cadaverine. Assimilation of L-lysine is positive or weak.

Growth occurs at $30^{\circ} \mathrm{C}$ but not at $37^{\circ} \mathrm{C}$.

Growth does not occur in vitamin-free medium.

Growth does not occur on 50\% (wt/wt) glucose-yeast extract agar.

No starch-like substance is produced.

Does not liquefy gelatin.

Acid production on chalk agar is weak.

Grows in the presence of $1 \mathrm{mg}$ of cycloheximide per $\mathrm{ml}$.

Does not grow in the presence of $5 \% \mathrm{NaCl}$.

The $\mathrm{G}+\mathrm{C}$ content of the nuclear DNA is 36.5 to $37.5 \mathrm{~mol} \%$, as determined by HPLC (Table 1).

Urease negative.

Does not hydrolyze casein.

The diazonium blue $\mathrm{B}$ reaction is negative.

Lipase negative.

The major ubiquinone is Q-8 (Table 2).

The type strain of $A$. fermentans, strain 80D2303, was isolated from soil from a papaya orchard in I'lan, Taiwan; strains 80D2406 and 80D2412 were isolated from soil samples from carambola orchards in Hualein, Taiwan. These strains have been deposited in the Culture Collection and Research Center, Food Industry Research and Development Institute, 
TABLE 1. DNA base compositions and levels of DNA relatedness between species belonging to the genus Arthroascus

\begin{tabular}{|c|c|c|c|c|}
\hline \multirow[b]{2}{*}{ Species } & \multirow[b]{2}{*}{ Strain } & \multirow{2}{*}{$\begin{array}{c}\mathrm{G}+\mathrm{C} \\
\text { content } \\
(\mathrm{mol} \%)\end{array}$} & \multicolumn{2}{|c|}{ \% DNA relatedness to: } \\
\hline & & & $\begin{array}{l}\text { A. fermentans } \\
80 \mathrm{D} 2303^{\mathrm{T}}\end{array}$ & $\begin{array}{l}\text { A. javanensis } \\
\text { CCRC } 21392^{\mathrm{T}}\end{array}$ \\
\hline \multirow[t]{3}{*}{ A. fermentans } & $80 \mathrm{D} 2303^{\mathrm{T}}$ & 37.5 & 100 & 32 \\
\hline & $80 \mathrm{D} 2406$ & 37.5 & 94 & 31 \\
\hline & $80 \mathrm{D} 2412$ & 36.5 & 100 & 30 \\
\hline A. javanensis & CCRC $21392^{\mathrm{T}}$ & 37.5 & 29 & 100 \\
\hline \multirow[t]{3}{*}{ A. schoenii } & CCRC 21401 & 43.5 & 25 & 41 \\
\hline & CCRC $22503^{\mathrm{T}}$ & 41.6 & 18 & 32 \\
\hline & CCRC 22504 & 42.3 & 20 & 36 \\
\hline
\end{tabular}

Hsinchu, Taiwan, as strains CCRC 22530, CCRC 22531, and CCRC 22532, respectively.

\section{DISCUSSION}

We classified the three newly isolated strains in the genus Arthroascus because they have characteristics typical of the genus Arthroascus, such as spindle-shaped asci, lemon-shaped or elongate cells, oblate ovoidal ascospores with ledges (6), a Q-8 ubiquinone system (Table 2), and a limited carbon assimilation pattern (2). However, these organisms differ from the two previously described Arthroascus species, A. javanensis and $A$. schoenii, in sporulation characteristics and fermentation ability. A. javanensis produces asci that contain one or (less frequently) two spores that have warty surfaces. The spores of this species clearly have a subequatorial ring, which imparts a helmet-shaped appearance to the spores (1). A. schoenii produces asci that contain two to four (sometimes six to eight) helmet-shaped ascospores with smooth surfaces (1). In $A$. fermentans, two to four oblate ovoidal spores with thin equatorial ledges and smooth surfaces are formed in each ascus. The diameter of $A$. fermentans spores (1.8 to $2.2 \mu \mathrm{m}$ ) is less than the diameter of $A$. javanensis spores $(4 \mu \mathrm{m})$.

$A$. fermentans assimilates few carbon compounds, like the other Arthroascus species, but it ferments glucose vigorously, while the other Arthroascus species do not ferment this compound (2).

Additional evidence that $A$. fermentans represents a new species comes from the findings that $A$. fermentans differs from

TABLE 2. Ubiquinone systems of Arthroascus species

\begin{tabular}{llllr}
\hline \multirow{2}{*}{$\begin{array}{c}\text { Species } \\
\end{array}$} & \multicolumn{2}{c}{ Strain } & \multicolumn{3}{c}{$\begin{array}{c}\text { \% the following ubiquinone } \\
\text { isoprenologs: }\end{array}$} \\
\cline { 3 - 5 } & & Q-6 & Q-7 & Q-8 \\
\hline A. fermentans & 80D2303 & 2.2 & 7.3 & 90.5 \\
& 80D2406 & 0.0 & 0.0 & 100.0 \\
& 80D2412 & 0.0 & 5.6 & 94.4 \\
A. javanensis & CCRC 21392 & 0.0 & 0.0 & 100.0 \\
A. schoenii & CCRC 21401 & 0.0 & 0.0 & 100.0 \\
& CCRC 22503 & 0.0 & 1.6 & 98.4 \\
& CCRC 22504 & 0.0 & 2.1 & 97.9 \\
\hline
\end{tabular}

A. schoenii in nuclear DNA base composition and that $A$. javanensis and $A$. schoenii exhibit low levels of DNA relatedness to the type strain of $A$. fermentans (Table 1). All of the $A$. fermentans strains exhibited high levels of DNA relatedness to the type strain of $A$. fermentans. Our genome comparison (Table 1) also revealed that $A$. schoenii is a species that is distinct from $A$. javanensis, as described by Smith et al. (8), although the physiological characteristics of the two species are very similar $(2,8)$.

Although the three strains of $A$. fermentans were isolated from soils, as was the only known strain of $A$. javanensis, the true habitats of these two species could be plant species growing in the soils. On the other hand, A. schoenii appears to occur in exudates of Quercus species in Russia, as well as in California (1).

\section{ACKNOWLEDGMENTS}

We thank the Ministry of Economic Affairs, Republic of China, for financial support.

We thank I. Banno, Institute for Fermentation, Osaka, Japan, for his available suggestions and T. Y. Liu and W. H. Hsu, Food Industry Research and Development Institute, Taiwan, Republic of China, for their encouragement.

\section{REFERENCES}

1. Bab'eva, I. P., M. M. Vustin, G. I. Naumov, and M. E. Vinovarova. 1985. Arthroascus schoenii nov. comb., a yeast-like organism. Mikrobiologiya 54:724-729.

2. Barnett, J. A., R. W. Payne, and D. Yarrow. 1990. Yeasts: characteristics and identification, 2nd ed. Cambridge University Press, Cambridge.

3. Collins, M. D., T. Pirouz, and M. Goodfellow. 1977. Distribution of menaquinones in actinomycetes and corynebacteria. J. Gen. Microbiol. 100:221-230.

4. Kaneko, Y., and I. Banno. 1991. Reexamination of Saccharomyces bayanus strains by DNA-DNA hybridization and electrophoretic karyotyping. Inst. Ferment. Res. Commun. (Osaka) 15:30-41.

5. Klöcker, A. 1909. Endomyces javanensis nov. sp. C. R. Trav. Lab. Carlsberg 7:267-272.

6. Kreger-van Rij, N. J. W. 1984. Arthroascus von Arx, p. 114-116. In N. J. W. Kreger-van Rij (ed.), The yeasts, a taxonomic study, 3rd ed. Elsevier Science Publishers B. V., Amsterdam.

7. Nakase, T., M. Itoh, A. Takematsu, K. Mikata, I. Banno, and Y. Yamada. 1991. Kockovaella, a new ballistospore-forming anamorphic yeast genus. J. Gen. Appl. Microbiol. 37:175-197.

8. Smith, M. T., G. A. Poot, and W. H. Batenburg-van der Vegte. 1990. Genome comparison among species of the genus Arthroascus van Arx. Antonie Leeuwenhoek 58:249-253.

9. Stelling-Dekker, N. M. 1931. Die sporogenen Hefen. Verh. K. Akad. Wet. Amsterdam Tweede Sect. 28:1-547.

10. Tamaoka, J., and K. Komagata. 1984. Determination of DNA base composition by reversed-phase high performance liquid chromatography. FEMS Microbiol. Lett. 25:125-128.

11. van der Walt, J. P., and D. Yarrow. 1984. Methods for isolation, maintenance, classification and identification of yeasts, p. 45-104. In N. J. W. Kreger-van Rij (ed.), The yeasts, a taxonomic study, 3rd ed. Elsevier Science Publishers B. V., Amsterdam.

12. von Arx, J. A. 1972. On Endomyces, Endomycopsis and related yeast-like fungi. Antonie Leeuwenhoek 38:289-309.

13. Wickerham, L. J., and K. Burton. 1954. A simple technique for obtaining mating types in heterothallic diploid yeasts, with special reference to their uses in the genus Hansenula. J. Bacteriol. 67:303-308. 